Chirurgia (2018) 113: 799-808

No. 6, November-December

Copyright $\odot$ Celsius

http://dx.doi.org/10.21614/chirurgia.113.6.799

\title{
EUS-Guided Transgastric Drainage of Intraabdominal Fluid Collections
}

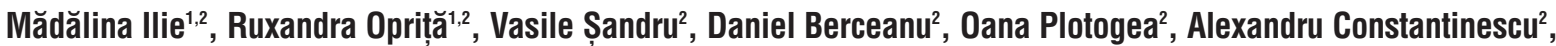 \\ Diana Diaconescu' ${ }^{2}$, Ionuț Negoi ${ }^{1,3}$, Gabriel Constantinescu, ${ }^{1,2}$
}

'University of Medicine and Pharmacy "Carol Davila", Bucharest, Romania

${ }^{2}$ Department of Gastroenterology, Clinical Emergency Hospital Bucharest, Romania

${ }^{3}$ Department of Surgery, Clinical Emergency Hospital Bucharest, Romania

Corresponding author:

Vasile Sandru, MD

Clinical Emergency Hospital

Gastroenterology Department

Bucharest, Romania

E-mail: drsandruvasile@gmail.com
Received: 15.10 .2018

Accepted: 10.12 .2018

\section{Rezumat \\ Drenajul transgastric ecoendoscopic-ghidat al colectiilor fluide intraabdominale}

Colectiile intraabdominale pot reprezenta o cauză semnificativă de morbiditate şi mortalitate în cazul pacienților cu pancreatită acută, precum şi al pacienților ce au suferit intervenții chirurgicale în general dar şi pentru patologie oncologică. În prezent tratamentul este centrat pe tehnicile minim-invazive, astfel încât recuperarea pacientului să fie de scurtă durată şi calitatea vieții să fie crescută. În ultima decadă, ecoendoscopia a început să fie folosită tot mai des alături de drenajele percutane şi de cele chirurgicale în managementul colecțiilor perigastrice.

Obiective: Principalul obiectiv al acestei lucrări este evaluarea ratei de succes tehnic şi clinic a drenajului ecoendoscopic ghidat al colectiilor intraabdominale. Obiectivele secundare sunt urmărirea rezoluției colectiilor intra-abdominale, apariția infectiilor postprocedurale, supraviețuirea.

Metode: Am realizat un studiu prospectiv observational a 31 de pacienți diagnosticați ecoendoscopic cu colecții intraabdominale fluide perigastrice, din totalul de 788 ecoendoscopii realizate intr-un interval de 2 ani. Pacienții au fost urmăriți timp de 6 luni post-procedural prin examinări iterative ecografice, endoscopice, tomografice. Toți pacienții incluşi în studiu au fost internați în Spitalul Clinic de Urgență Bucureşti, în secțiile de gastroenterologie şi chirurgie. Datele colectate au fost procesate utilizând IBM SPSS Statistics 20. 
Rezultate: Vârsta medie a subiecților incluşi în studiu a fost 51 de ani. Diametrul mediu al colecțiilor intraabdominale a fost de $109 \mathrm{~mm}(34-250 \mathrm{~mm})$, acesta corelându-se cu metoda de tratament aleasă $(p<0.005)$ : drenaj ghidat eco-endoscopic, drenaj percutan, intervenție chirurgicală, ca monoterapie sau combinații între acestea. Mortalitatea peri-procedurală a fost de $9,3 \%$, asociată în principal cu severitatea patologiei ori cu asocierea chirurgiei în tratament.

Concluzii: În conluzie, prin studiul efectuat putem afirma că ecoendoscopia poate fi metoda de primă intenție în a drena colecțiile intra abdominale perigastrice, pentru că reprezintă o metodă sigură şi eficientă, cu un success tehnic de $100 \%$ în timp ce succesul clinic de peste $80 \%$ asigură o mai bună calitate a vieții. Pentru colecțile ce au un diametru mai mare de $127 \mathrm{~mm}$, ne putem aştepta totuşi la necesitate unui tratament combinat, ecoendoscopic şi chirurgical.

Cuvinte cheie: colecții intraabdominale, drenaj transgastric, percutan, chirurgie, ecoendoscopie

\section{Abstract}

Intraabdominal fluid collections can be a significant cause of morbi-mortality among patients with acute pancreatitis and those who underwent surgery, especially oncological ones. Nowadays, the treatment tends to be minimally invasive, so that the patient's recovery would be shorter and the quality of life higher. EUS (endoscopic ultrasound) has emerged in the last decade to fulfill that demand, alongside percutaneous and surgical drainage in the management of perigastric collections.

Objectives: The main objective of this paper is to evaluate the efficacy of EUS guided drainage in terms of techincal and clinical success. Secondary objectives refer to the assessment of complete resolution of intraabdominal collection, presence of infection after drainage, overall survival.

Methods: We conducted a prospective study by enrolling 31 patients who were diagnosed using EUS with perigastric intraabdominal fluid collections, from an overall of 788 EUS performed over a period of 2 years. We analyzed their evolution during 6 months after treatment, by regular examinations (ultrasound/endoscopic/computed tomography). All of them were in-patients of Bucharest Clinical Emergency Hospital, either in Endoscopy or in Surgery Departments. Data collected was processed in IBM SPSS Statistics 20.

Results: Overall mean age was 51 year and intraabdominal collections average was $109 \mathrm{~mm}$ (range 34 $-250 \mathrm{~mm})$ and was correlated with the method of treatment $(\mathrm{p}<0.005)$. Patients underwent different methods for their intraabdominal collections: EUS drainage, CT (computed-tomography)guided percutaneous drainage, surgical intervention, alone or combined when needed. Overall mortality was $9,3 \%$ and was mainly related to the severity of the case and sepsis.

Conclusions: We conclude that endoscopic ultrasound can be the first choice for drainage of intraabdominal perigastric fluid collections because it is a safe and effective technique with $100 \%$ technical success, and with over $80 \%$ clinical success assures a better quality of life. For collections with a diameter larger than $127 \mathrm{~mm}$, we can expect however the need of combined treatment, EUS and surgery.

Key words: intraabdominal collections, transgastric drainage, percutaneous, surgery, endoscopic ultrasound (EUS)

\section{Introduction}

Intraabdominal fluid collections consist mainly of walled-off pancreatic necrosis (WOPN) and pseudocysts. WOPN is derived from necrotic parenchyma and/or necrotic peripancreatic tissues and may be infected, multiple, or may be present at sites distant from the pancreas (1). 
Pseudocysts are localized fluid collections, surrounded by non-epithelial wall (granulation tissue or connective tissue) that usually appear after the rupture or obstruction of a pancreatic duct. Other pseudocysts come from the liquefaction of an area of necrosis, with detritus and secretions remaining encapsulated (2). They can be intrapancreatic (usually small) or extrapancreatic. In most cases, they are delimited by the connective tissue or the surrounding organs. It is considered that a period of time of at least 4 weeks must pass from their appearance until they acquire a mature wall (3).

Another type of intraabdominal collections described in the literature to have been drained by EUS guidance are postoperative intraabdominal and pelvic fluid collections that have appeared after surgery and oncological surgery, such as perigastric abscesses, perigastric hematoma, rectal hematoma, perirectal biloma and perirectal abscess $(4,5)$.

Surgery procedures usually related to the collections are intestinal reconnection, distal pancreatectomy, biliary-digestive bypass, exploratory laparotomy and bariatric surgery (6).

\section{Pancreatic and Intraabdominal Fluid Collections}

Up to $40 \%$ cases of acute pancreatitis develop collections, from which $80 \%$ are spontaneously reabsorbed, while the remaining $20 \%$ evolve into proper pseudocysts. Of these, half will be reabsorbed or stabilised, while the other half will be those with clinical relevance. Between 20 and $40 \%$ of chronic pancreatitis develop pseudocysts in the first 5 years after being diagnosed, some of which will have clinical relevance because of their evolution, size or location (7).

When the pseudocysts have clinical relevance, the most frequent symptoms, regardless of their origin, are: pain $(75 \%)$, nausea $(50 \%)$, low-grade fever, weight loss, palpable mass, jaundice and increased inflammatory syndrome. Some pseudocystsb may complicate with obstruction of enteric, biliary or vascular transit, pseudoaneurysm, hemorrhage, infection and rupture. When the pseudocysts are large, their spontaneous resolution is rare and their therapeutic aproach becomes more difficult. In general, pseudocysts of $6 \mathrm{~cm}$ or less than $6 \mathrm{~cm}$ can be approached with conservative treatment (8). Taking the decision when to treat a pseudocyst may be complicated, since large pseudocysts diagnosed in the course of acute pancreatitis can disappear spontaneously. Classically, it was considered that a pseudocyst must be drained when it was greater than $6 \mathrm{~cm}$ and persisted for more than 6 weeks. Today, there is a tendency towards close monitoring and indicating treatment when the pseudocyst perpetuates symptoms, grows or becomes complicated (9). The drainage of the pseudocysts can be surgical, percutaneous or endoscopic. In the past, surgical treatment was considered the "gold standard", although it was not exempt from significant morbidity and mortality. Nowadays there is a tendency to perform minimally invasive treatments (10).

Intraabdominal abscesses can be classified according to their origin in: post-pancreatitis, post-surgical or post-traumatic. After an episode of pancreatitis, abscesses result from the liquefaction of an area of necrosis, of a peri-pancreatic collection or a pseudocyst that became infected. This happens spontaneously by bacterial translocation in up to $10 \%$ of cases, with signs of infection appearing 20-40 days after the acute episode or, more frequently, iatrogenic after inadequate intervention (11).

Postsurgical abscesses are formed by external contamination of the surgical field or, more likely, by contamination from the intestinal lumen itself during surgical manipulation. The post-traumatic ones appear after injuries of the pancreas or after traumatic pancreatitis associated with the rupture of contaminated nearby viscera. Treatment should always include adequate antibiotic therapy, although this is insufficient and mortality in pancreatic abscess is very high if it is not drained. The approaching method of the abscesses is similar to that of pseudocysts, nowadays tending towards minimally invasive techniques (12). 


\section{Endoscopic Ultrasound-guided Drainage}

Endoscopic ultrasound allows description of the lesion and its distance from the gastric wall. It also allows to identify interposed vessels or structures and to describe the type of lesion and the characteristics of its contents before being punctured, in order to exclude vascular structures. The great advantage of endoscopic ultrasound is the possibility of seeing in real time, within the ultrasound plane, the material introduced into the working channel. A linear echoendoscope is used to perform these procedures.

Until a few years ago, there were available only echoendoscopes with small-gauge working channel that allowed the introduction of 7Fr double pigtail prostheses. Today there are therapeutic echoendoscopes that allow the insertion of double pigtail prostheses up to 10 Fr. When a therapeutic device is not available, there might be another possibility: to place a guidewire inside the lesion using an echoendoscope and a puncture needle, and then to proceed the intervention with a lateral-viewing endoscope (13,14) (Fig. 1).

After the development of therapeutic echoendoscopes, and taking into consideration the laborious nature of the classical approach, new prosthesis placement systems have been designed in a single step procedure, such as lumen-apposing metal stents (LAMS) with electrocautery enhancement -Hot Axios Boston Scientific or without - Axios - Boston Scientific; Nagi stent, Spaxus stent-Taewoong medicalor Hanaro stent-M.I. Tech. These systems consist of a modified papillotome that allows the passage of a wire with variable hardness, a prosthesis located on the papillotome that performs the functions of introducer and a pusher or positioner catheter $(15,16)$ (Fig. 2).

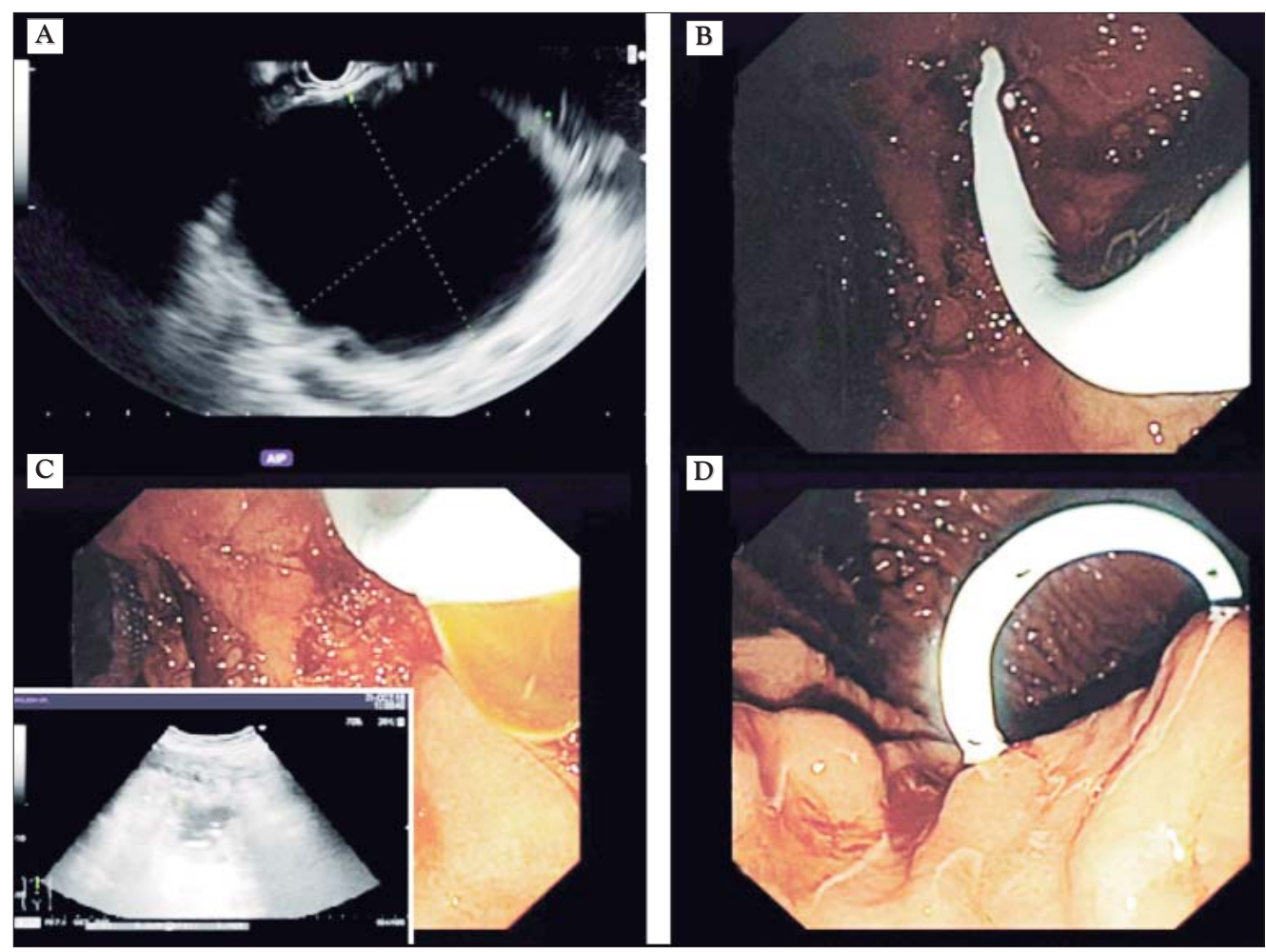

Figure 1. (A) - EUS view of pancreatic pseudocyst before drainage; (B) - Transgastric insertion of double pigtail 10Fr stent; (C) - Endoscopic view of the pancreatic pseudocyst content/Ultrasound view after partial drainage; (D) - Endoscopic view of the final position of the stent in the stomach. From Bucharest Clinical Emergency Hospital, Endoscopy Department 


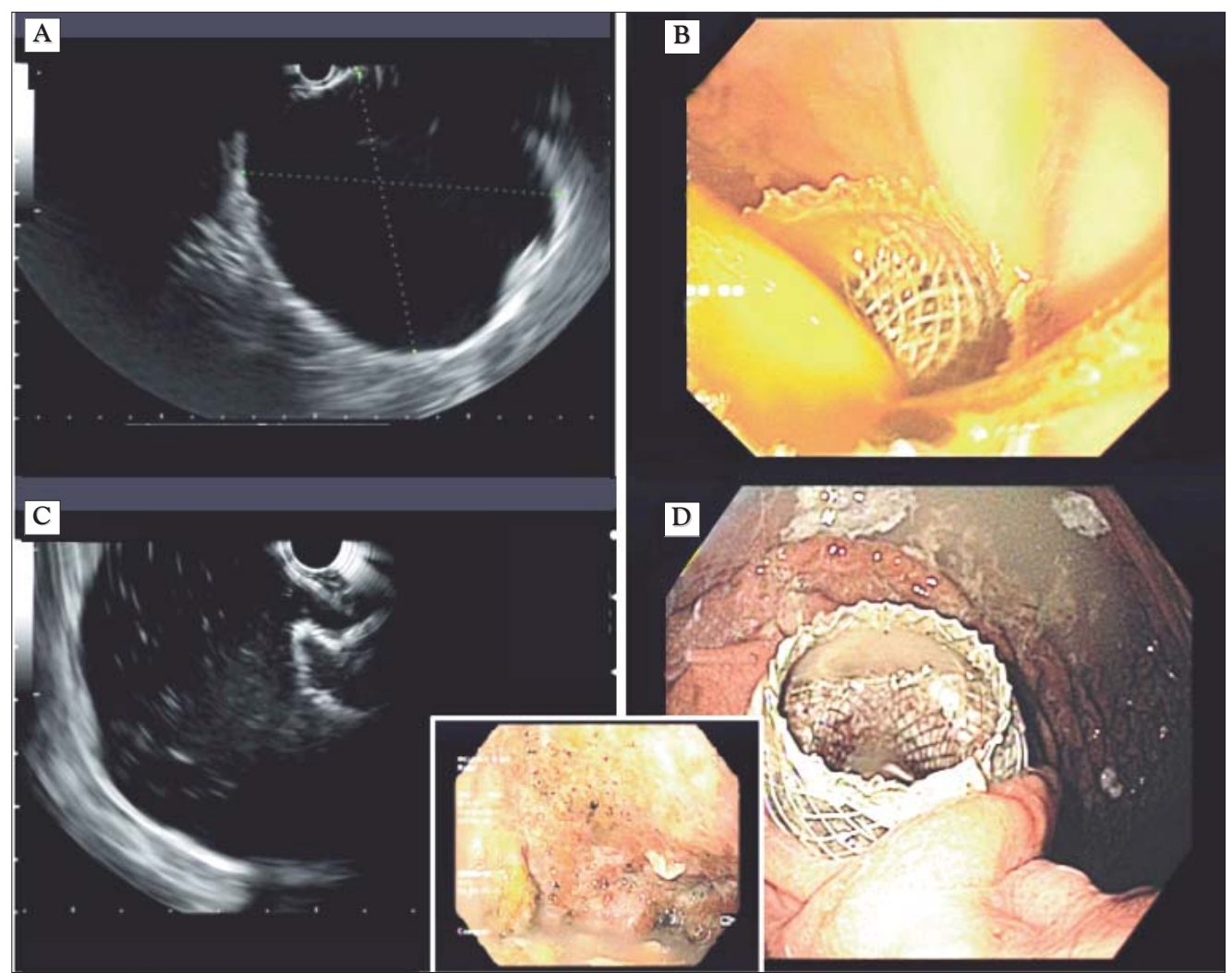

Figure 2. (A) - EUS view of WOPN; (B) - Endoscopic view of LAMS with immediate evacuation of puss from the infected collection; (C) - EUS view of the hyperechoic internal flange of LAMS;

(D) - Endoscopic view of Hot Axios located intragastric/ Internal endoscopic view of the collection after drainage as seen through LAMS.

From Bucharest Clinical Emergency Hospital, Endoscopy Department

With very good results, before the development of LAMS the self-expandable fully covered metallic stents were and are still used with success in the drainage of intraabdominal fluid collections, but with a higher risk of migration than LAMS. All these devices have revolutionised the drainage of intraabdominal fluid collections (17) (Fig. 3).

These systems described above shorten the procedure duration by more than $80 \%$ and, in selected cases; they allow to perform the entire procedure exclusively with echoendoscopic control, avoiding the use of X-rays.The use of LAMS has emerged in the last years not only for the drainage of intraabdominal fluid collections but also for the palliation of malignant biliary-duodenal obstruction $(18,19)$.

\section{Materials and Methods}

The main objective of this paper is to evaluate the efficacy of EUS drainage in terms of

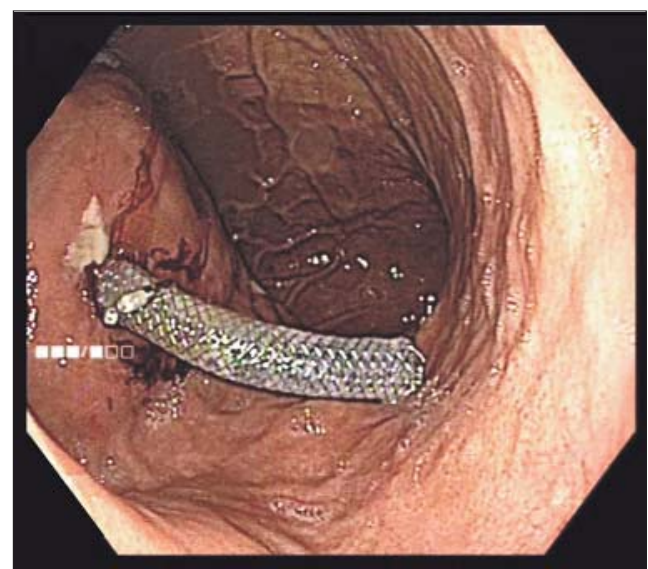

Figure 3. Endoscopic view of self-expandable fully covered metallic stent 
technical and clinical success. Secondary objectives refer to the assessment of complete resolution of intraabdominal collection, presence of infection after drainage, overall survival.

We conducted a prospective observational study by enrolling 31 patients who were diagnosed using EUS with perigastric intraabdominal fluid collections, from an overall of 788 EUS made over a period of 2 years-May 2016-May 2018. We analyzed their evolution during 6 months after treatment, by regular examinations (ultrasound/endoscopic/computed tomography). All of them were in-patients of Bucharest Clinical Emergency Hospital, either in Endoscopy or in Surgery Departments. Data collected was processed in IBM SPSS Statistics 20.

In 4 cases the treatment was only surgical, while the other patients were approached by: only computed-tomography-guided percutaneous drainage (1 patient), endoscopic ultrasound-guided drainage (11 patients), combined computed-tomography-guided percutaneous and EUS drainage (1 patient), combined EUSdrainage and surgical (4 patients). 10 patients were treated conservatory.

\section{Results}

Overall mean age was 51 year and intraabdominal collections average was $109 \mathrm{~mm}$ (range $34-250 \mathrm{~mm}$ ). Collections drained only endoscopically had an average diameter of 127 $\mathrm{mm}$. Patients with collections drained firstly by EUS but eventually needed surgery due to large amount of necrosis, multiple collections or infected collections after initial drainage had a mean diameter of $166 \mathrm{~mm}$. Surgery was performed when the collections had an average of $145 \mathrm{~mm}$ (with a range $90-250$ $\mathrm{mm})$. Collections with a mean diameter of 58 $\mathrm{mm}$ were successfully treated by conservatory treatment.

Most of intraabdominal collections were caused by acute pancreatitis and the drainage was performed more than 4 weeks later. 2 intraabdominal collections appeared after abdominal trauma with rupture of the pancreatic duct, wich needed extensive intraabdominal surgery and one case appered after duodeono-pancreatectomy for pancreatic head cancer. The low number of post-surgery collections could be explained by the fact that surgeons usually reintervene.

From the cases treated by endoscopic ultrasound-guided drainage, 6 patients underwent drainage with double pigtail plastic stent, 5 of them with good results after 4-6 weeks when the stents were removed. In one case, the patient returned 1 month after stent extraction with multiple infected collections which were approached surgically but with a bad outcome (no.1 in Table 1). 6 collections were drained with self-expandable fully covered metallic stents, 5 being successfully drained, but one needing eventually surgery due to transgastric migration (no.7 in Table 1).

Electrocautery enhanced lumen-apposing stents (Hot Axios 15/10 mm Boston Scientific) were used to treat 6 patients. On average these patients needed 3 sessions of necrosectomy until full resolution of the collection. From these patients, one patient was sent to surgery because fever appeared 2 days after stent extraction, which was accompanied by abdominal pain (no. 8 in Table 1). During surgery, the collection proved to be more extended that initially evaluated. One patient developed mild pneumoperitoneum after LAMS extraction, which was treated conservatory (no. 3 in Table 1).

Technical success rate was 100\% regarding stents insertion (either plastic or metallic), while clinical success rate $83 \%$ for Hot Axios transgastric placement, $80 \%$ for both plastic and metallic stents drainage.

Overall mortality was $9,3 \%$ and was mainly related to the severity of the case, all patients had septic collections. Supplementary data should be obtained from randomized studies in order to optimize the management of these patients.

\section{Discussions}

Treatment of intraabdominal collections should be approached in a multidisciplinary way. First 
Table 1. Patients table

\begin{tabular}{|c|c|c|c|c|c|c|c|c|}
\hline No & Initials & Sex & Age & $\begin{array}{l}\text { Collection max. } \\
\text { diameter }(\mathrm{mm})\end{array}$ & $\begin{array}{l}\text { Type of } \\
\text { collection }\end{array}$ & $\begin{array}{l}\text { Therapeutical } \\
\text { approach }\end{array}$ & $\begin{array}{l}\text { Type of } \\
\text { stent used }\end{array}$ & $\begin{array}{l}\text { Post-procedural } \\
\text { evolution/complications }\end{array}$ \\
\hline 1 & BS & $\mathrm{F}$ & 59 & 140 & $\begin{array}{l}\text { Pancreatic } \\
\text { pseudocyst }\end{array}$ & EUS+surgery & $\begin{array}{l}2 x \text { double pigtail } \\
(10 \mathrm{Fr}, 7 \mathrm{Fr})\end{array}$ & Death/Sepsis \\
\hline 2 & $\mathrm{BE}$ & $\mathrm{F}$ & 61 & 200 & $\begin{array}{l}\text { Pancreatic } \\
\text { pseudocyst }\end{array}$ & EUS & $\begin{array}{l}\text { fully covered metallic } \\
\text { stent }(100 \times 10 \mathrm{~mm})\end{array}$ & Full recovery \\
\hline 3 & BM & $\mathrm{F}$ & 50 & 80 & WOPN & EUS & Hot Axios $15 / 10 \mathrm{~mm}$ & $\begin{array}{l}\text { Full recovery/ pneumoperitoneum after } \\
\text { Hot Axios extraction treated conservatory }\end{array}$ \\
\hline 4 & $\mathrm{BP}$ & M & 57 & 75 & WOPN & $\begin{array}{l}\text { EUS }+C T \text { guided } \\
\text { percutaneous }\end{array}$ & $\begin{array}{l}\text { Hot Axios } 15 / 10 \mathrm{~mm} \\
\text { and } 7 \text { Fr double pigtail } \\
\text { permanent }\end{array}$ & $\begin{array}{l}\text { Full recovery; disconnected pancreatic duct } \\
\text { syndrome with EUS guided internal drainage }\end{array}$ \\
\hline 5 & CC & M & 18 & 156 & $\begin{array}{l}\text { Pancreatic injury grade } \\
3 \text { with perisplenic post } \\
\text { surgery collection }\end{array}$ & EUS & $\begin{array}{l}\text { fully covered metallic } \\
\text { stent }(80 \times 8 \mathrm{~mm})\end{array}$ & Full recovery \\
\hline 6 & $\mathrm{CM}$ & $\mathrm{F}$ & 50 & 200 & WOPN & EUS & $\begin{array}{l}2 \times \text { double pigtail }(7 \mathrm{Fr}) \\
\text { and fully covered metallic } \\
\text { stent }(100 \times 10 \mathrm{~mm})\end{array}$ & Full recovery \\
\hline 7 & DM & $\mathrm{F}$ & 49 & 190 & $\begin{array}{l}\text { Pancreatic } \\
\text { pseudocyst }\end{array}$ & EUS+surgery & $\begin{array}{l}\text { fully covered metallic } \\
\text { stent }(100 \times 10 \mathrm{~mm})\end{array}$ & $\begin{array}{l}\text { Fully covered metallic stent intra-collection } \\
\text { migration, surgery with full recovery }\end{array}$ \\
\hline 8 & FP & M & 44 & 250 & WOPN & EUS+surgery & Hot Axios $15 / 10 \mathrm{~mm}$ & $\begin{array}{l}\text { Good drainage of fluid content, due to large } \\
\text { amount of necrosis, underwent surgery with } \\
\text { full recovery }\end{array}$ \\
\hline 9 & IS & $\mathrm{F}$ & 73 & 130 & WOPN & EUS & Hot Axios $15 / 10 \mathrm{~mm}$ & Full recovery \\
\hline 10 & MV & $\mathrm{M}$ & 40 & 110 & Pancreatic pseudocyst & EUS & Hot Axios $15 / 10 \mathrm{~mm}$ & Full recovery \\
\hline 11 & MT & M & 63 & 90 & Pancreatic pseudocyst & EUS & double pigtail $10 \mathrm{Fr}$ & Full recovery \\
\hline 12 & RN & M & 49 & 87 & Pancreatic pseudocyst & EUS+surgery & $\begin{array}{l}\text { fully covered metallic } \\
\text { stent }(100 \times 10 \mathrm{~mm})\end{array}$ & $\begin{array}{l}\text { Good drainage of pseudocyst, due to } \\
\text { multiple collections, underwent surgery with } \\
\text { full recovery }\end{array}$ \\
\hline 13 & ST & $\mathrm{M}$ & 67 & 56 & Pancreatic pseudocyst & EUS & double pigtail $10 \mathrm{Fr}$ & Full recovery \\
\hline 14 & SP & $F$ & 66 & 130 & WOPN & EUS & Hot Axios $15 / 10 \mathrm{~mm}$ & Full recovery \\
\hline 15 & TM & M & 49 & 150 & Pancreatic pseudocyst & EUS & $\begin{array}{l}\text { fully covered metallic } \\
\text { stent }(100 \times 10 \mathrm{~mm})\end{array}$ & Full recovery \\
\hline 16 & VD & M & 37 & 100 & $\begin{array}{l}\text { Pancreatic injury grade } 3 \\
\text { with post surgery collection }\end{array}$ & EUS & $\begin{array}{l}\text { double pigtail } 7 \mathrm{Fr} \\
\text { permanent }\end{array}$ & Full recovery \\
\hline 17 & $\mathrm{BP}$ & $\mathrm{M}$ & 53 & 250 & Pancreatic pseudocyst & Surgery & No & Full recovery \\
\hline 18 & CT & M & 69 & 50 & Pancreatic pseudocyst & Conservatory & No & Full recovery \\
\hline 19 & $\mathrm{CC}$ & M & 33 & 54 & Pancreatic pseudocyst & Conservatory & No & $20 \mathrm{~mm}$ at final follow up \\
\hline 20 & DM & M & 43 & 50 & Pancreatic pseudocyst & Conservatory & No & Full recovery \\
\hline 21 & $D G$ & M & 55 & 120 & WOPN & Surgery & No & Death/Sepsis \\
\hline 22 & DM & $\mathrm{F}$ & 77 & 80 & $\begin{array}{l}\text { Collection after duodeono- } \\
\text { pancreatectomy for } \\
\text { pancreatic head cancer }\end{array}$ & $\begin{array}{l}\text { CT guided } \\
\text { percutaneous }\end{array}$ & No & Full recovery \\
\hline 23 & MD & $\mathrm{F}$ & 59 & 60 & $\begin{array}{l}\text { Post pancreatitis - acute } \\
\text { collection }\end{array}$ & Conservatory & No & $18 \mathrm{~mm}$ at final follow up \\
\hline 24 & IM & M & 36 & 120 & $\begin{array}{l}\text { Pancreatic tail } \\
\text { non-malignant cyst }\end{array}$ & $\begin{array}{l}\text { Surgery in } \\
\text { Heidelberg, } \\
\text { Germany }\end{array}$ & No & Full recovery \\
\hline 25 & MC & $\mathrm{F}$ & 51 & 40 & Pancreatic pseudocyst & Conservatory & No & Full recovery \\
\hline 26 & MA & M & 50 & 150 & WOPN & Conservatory & No & $74 \mathrm{~mm}$ at final follow up \\
\hline 27 & MM & M & 30 & 40 & Pancreatic pseudocyst & Conservatory & No & Full recovery \\
\hline 28 & SM & $F$ & 48 & 34 & WOPN & Conservatory & No & Full recovery \\
\hline 29 & SA & $\mathrm{F}$ & 56 & 38 & WOPN & Conservatory & No & Full recovery \\
\hline 30 & TG & M & 42 & 90 & Infected WOPN & Surgery & No & Death/Sepsis \\
\hline 31 & TN & $\mathrm{M}$ & 48 & 65 & Pancreatic pseudocyst & Conservatory & No & Full recovery \\
\hline
\end{tabular}


of all, an adequate diagnosis must be made and the need for treatment established. The procedure should be assessed depending on the experience of each center and/or the possibility to refer the patient to a more experienced center. Using EUS guided drainage of the collection is part of the modern management and should be taken into account before surgery (which has higher morbidity and mortality rates) (20). The advantages of minimally invasive techniques are the fact the patient's recovery time will be shorter and the quality of life will increase, with overall less economic impact $(21,22)$.

EUS allows a better characterization of the lesion, is it a pseudocyst or other type of cystic lesion that should not be drained? The differential diagnosis is broad, and includes benign cysts $(<5 \%)$, cystic neoplasms of the pancreas (5-10\%) and true pseudocysts (80-90\%). The existence of a previous history of acute or chronic pancreatitis or an etiological antecedent that explains it, must be considered for the diagnosis (23). Generally, pseudocysts are lesions with more or less anechoic content, often with a more echogenic level on their lower side depending on detritus, necrotic tissue or hematic remains. They may contain septations and usually echogenic and regular walls, without focal thickening or vegetating projections towards its interior, without calcium in its wall and with high amylase content (24).

Using endoscopic ultrasound the nearest point of the lesion to the gastric wall can be located, this information is extremely useful when evaluating lesions that do not protrude onto the gastric wall. It also avoids confusion with other possible extrinsic impacts of the area. At the same time it allows to measure the distance between the cyst cavity or intrabdominal collection and the gastric lumen, considering that the risk of leakage into the peritoneum is reduced if the distance is equal or less than one centimeter, although this also depends on other factors such as its location or existence of inflammatory adhesions (25). Another fact that should be taken into account is the existence of submucosal vessels or true varicose veins that are not infrequently associated and that may be interposed between the gastric wall and the cyst. The use of color Doppler helps to identify these structures and maneuver the echoendoscope in order to avoid them when it comes to puncture (26).

The high resolution images provided by the echoendoscopes allow the precise description of the content of these lesions, so that they help to decide the number and characteristics of the drainage procedures that should be performed (27).

The complications following the procedure can be classified in immediate and late. Among immediate complications are described: the perforation of the peritoneum, the puncture of another internal organ and the hemorrhage of the gastric wall or intestinal wall.These complications are rather theoretical than practical when the technique is performed adequately and under real-time endoscopic ultrasound guidance. An immediate and endoscopically unpredictable complication is intracystic hemorrhage due to sudden decompression that conditions the rupture of a pseudoaneurysm (28).

Among late complications are bleeding produced by the prosthesis on a vessel in the inferior side of the pseudocyst and also infection. The first is unpredictable and, although infrequent, it is facilitated by the reduction in size and collapse of the cavity that makes the end of the prosthesis, which was previously free inside the pseudocyst, and now rests on the contralateral wall of the pseudocystup to the point of perforation. It is important to know that due to this risk the LAMS will be kept in place for a maxium of 3 weeks, while the plastic double pigtail stents can usually be extracted after 4-8 weeks. The infection may appear after the obstruction of the prosthesis (due to necrotic tissue)or might have already been present at the time of the procedure, case in which the treatment is that of an abscess or a collection with liquefied and infected necrosis $(29,30)$.

To avoid the premature obstruction of the LAMS with necrotic tissue, dilation with ballon of the stent may be necessary during the procedure and an endoscopic evaluation is mandatory 1-2 days after the insertion. The collection-gastrostomy site is left to close secondarily without the need of clipping or 
suturing after stent removal (31).

In order to adequately solve each case, the pattern that seems the most reasonable is:

a) Anechoic content and leakage of crystalline fluid: a single prosthesis may be sufficient.

b Content with detritus or echoic signal: several prostheses \pm nasocystic drainage or LAMS.

c) Clinical signs of infection or echoic, content with gas bubbles or pus extravasation: several prostheses + nasocystic drainageor LAMS + nasocystic drainage with continuous lavage with saline solution (32).

d) Content with solid areas or necrotic tissue with or without signs of infection: several prostheses + nasocystic drainage with continuous lavage with saline solution \pm endoscopic debridement (33) or LAMS \pm nasocystic drainage \pm endoscopic debridement. In this case, when the content of the lesion is very thick, a $15 \mathrm{~mm}$ gastrocystic fistula can be made with a balloon dilator; then, the gastroscopeis inserted into the cyst and with the help of a Dormiabasket the detritus can be extracted (34), in the absence of LAMS, case in which necrosectomy can be done via the lumen apposing stent.

\section{Conclusions}

We conclude that endoscopic ultrasound can be the first choice for drainage of intraabdominal perigastric fluid collections because it allows performing the entire procedure with images in real time, to characterize the lesion and its content and in most cases to also drain the collection in a single step technique. With $100 \%$ technical succes and over $80 \%$ clinical succes it is safe and assures a better quality of life, when collections have an average diameter of $\leq 127$ $\mathrm{mm}$. For collections with a larger diameter we can expect the need of combined treatment. In addition, it may help to identify pathophysiological mechanism, to choose the appropriate point for the puncture, to measure the thickness of the wall that needs to be passed and to detect the existence of interposed vessels in order to avoid them. Completing a 3 axes management alongside percutaneous drainage (ultrasound/ CT guided) and surgery, endoscopic ultrasound guided drainage offers to our patients the opportunity of an $360^{\circ}$ treatment.

\section{Conflict of Interest}

The authors declare no conflicts of interests.

\section{References}

1. Banks PA, Bollen TL, Dervenis C, et al. Classification of acute pancreatitis--2012: revision of the Atlanta classification and definitions by international consensus. Gut 2013;62(1):102-11.

2. Pan G, Wan MH, Xie KL, et al. Classification and Management of Pancreatic Pseudocysts. Medicine (Baltimore). 2015;94(24):e960.

3. Lerch MM, Stier A, Wahnschaffe U, Mayerle J. Pancreatic pseudocysts: observation, endoscopic drainage, or resection? Dtsch Arztebl Int. 2009;106(38):614-21.

4. Ulla-Rocha JL, Vilar-Cao Z, Sardina-Ferreiro R. EUS-guided drainage and stent placement for postoperative intra-abdominal and pelvic fluid collections in oncological surgery. Therap Adv Gastroenterol. 2012;5(2):95-102.

5. Mandai K, Uno K, Yasuda K. Endoscopic ultrasound-guided drainage of postoperative intra-abdominal abscesses. World $\mathrm{J}$ Gastroenterol. 2015;21(11):3402-8.

6. Téllez-Ávila F, Carmona-Aguilera GJ, Valdovinos-Andraca F, et al. Postoperative abdominal collections drainage: Percutaneous versus guided by endoscopic ultrasound.Dig Endosc. 2015;27(7): 762-6.

7. Tyberg A, Karia K, Gabr M, et al. Management of pancreatic fluid collections: A comprehensive review of the literature. World $\mathrm{J}$ Gastroenterol. 2016;22(7):2256-70.

8. Hao SJ, Xu WJ, Di Y, et al. Novel and supplementary management of pancreatic fluid collections: Endoscopic ultrasound-guided drainage. World J GastrointestEndosc. 2017;9(9):486-493.

9. Nabi Z, Basha J, Reddy DN. Endoscopic management of pancreatic fluid collections-revisited. World J Gastroenterol. 2017;23(15):26602672.

10. Easler J, Papachristou GI. The morphologic evolution of necrotic pancreatic fluid collections and their management. Asymptomatic: delay, defer and don't panic!. Ann Gastroenterol. 2014;27(3):191192.

11. Boumitri C, Brown E, Kahaleh M. Necrotizing Pancreatitis: Current Management and Therapies. ClinEndosc. 2017;50(4):357-365.

12. Park J, Charles HW. Intra-abdominal abscess drainage: interval to surgery. SeminInterventRadiol. 2012;29(4):311-3.

13. Vila JJ, Carral D, Fernández-Urien I. Pancreatic pseudocyst drainage guided by endoscopic ultrasound. World J Gastrointest Endosc. 2010;2(6):193-7.

14. Seewald S, Ang TL, Teng KC, Soehendra N.EUS-guided drainage of pancreatic pseudocysts, abscesses and infected necrosis.Dig Endosc. 2009 Jul;21Suppl 1:S61-5

15. Patil R, Ona MA, Papafragkakis C, Anand S, Duddempudi S. Endoscopic ultrasound-guided placement of AXIOS stent for drainage of pancreatic fluid collections. Ann Gastroenterol. 2016;29(2):168-73.

16. Mussetto A, Fugazza A, Fuccio L, et al. Current uses and outcomes of lumen-apposing metal stents. Ann Gastroenterol. 2018;31(5): 535-540.

17. Itoi T, Nageshwar Reddy D, Yasuda I.New fully-covered self- 
expandable metal stent for endoscopic ultrasonography-guided intervention in infectious walled-off pancreatic necrosis (with video).J HepatobiliaryPancreat Sci. 2013 Mar;20(3):403-6.

18. Sandru V, llie M, Plotogea 0 , et al. Endoscopic ultrasound-guided choledochoduodenostomy using a lumen apposing metal stent for acute cholangitis. Turk J Gastroenterol. 2018;29(4):511-514

19. Tyberg A, Perez-Miranda M, Sanchez-Ocaña R, et al. Endoscopic ultrasound-guided gastrojejunostomy with a lumen-apposing metal stent: a multicenter, international experience. Endosclnt Open. 2016;4(3):E276-81.

20. Andalib I, Dawod E, Kahaleh M.Modern Management of Pancreatic Fluid Collections.J ClinGastroenterol. 2018 Feb;52(2):97-104.

21. Surlin $V$ et al. A rare case of walled off pancreatic necrosis complicated by splenic artery rupture manifested after surgical internal drainage - diagnostic and therapeutic aspects" Chirurgia. 2018

22. Aparna D, Kumar S, Kamalkumar S. Mortality and morbidity in necrotizing pancreatitis managed on principles of step-up approach: 7 years experience from a single surgical unit. World $J$ Gastrointest Surg. 2017;9(10):200-208.

23. Chong CCN, Tang RSY, Wong JCT, Chan AWH, Teoh AYB. Endoscopic ultrasound of pancreatic lesions. J Vis Surg. 2016;2:119. Published 2016 Jul 22.

24. Eckardt AJ, Jenssen C. Current endoscopic ultrasound-guided approach to incidental subepithelial lesions: optimal or optional? Ann Gastroenterol. 2015;28(2):160-172.

25. Shekhar C, Maher B, Forde C, et al.Endoscopic ultrasound-guided pancreatic fluid collections' transmural drainage outcomes in 100 consecutive cases of pseudocysts and walled off necrosis: a singlecentre experience from the United Kingdom.Scand J Gastroenterol.
2018 May;53(5):611-615.

26. Alali A, Mosko J, May G, Teshima C. Endoscopic UltrasoundGuided Management of Pancreatic Fluid Collections: Update and Review of the Literature. ClinEndosc. 2017:50(2):117-125.

27. Bang JY, Varadarajulu S. Endoscopic ultrasound-guided management of pancreatic pseudocysts and walled-off necrosis. ClinEndosc. 2014;47(5):429-31.

28. Puri R, Mishra SR, Thandassery RB, et al. Outcome and complications of endoscopic ultrasound guided pancreatic pseudocyst drainage using combined endoprosthesis and naso-cystic drain.J GastroenterolHepatol. 2012;27(4):722-7.

29. Rasmussen DN, Hassan H, Vilmann P.Only few severe complications after endoscopic ultrasound guided drainage of pancreatic pseudocysts.Dan Med J. 2012;59(4):A4406.

30. Lakhtakia S.Complications of diagnostic and therapeutic Endoscopic Ultrasound.Best Pract Res Clin Gastroenterol. 2016; 30(5):807-823.

31. Adler DG, Taylor LJ, Hasan R, et al. A retrospective study evaluating endoscopic ultrasound-guided drainage of pancreatic fluid collections using a novel lumen-apposing metal stent on an electrocautery enhanced delivery system.Endosc Ultrasound. 2017:6(6):389-393.

32. Saumoy M, Arvanitakis M, Kahaleh M. Pancreatic fluid collections and necrosectomy with plastic stents versus lumen-apposing stents. Endosc Ultrasound. 2017;6(Suppl 3):S132-S137.

33. Pancreatic Pseudocyst Drainage Using Lumen-Apposing Metal Stents. GastroenterolHepatol (N Y). 2015;11(9):634-6.

34. Bansal RK, Puri R, Choudhary NS, et al. Endoscopic pancreatic necrosectomy: why scuff when you can flush the muck - make it an easy row to hoe. EndoscInt Open. 2017;5(9):E847-E853. 